FOSSIL PLANTS.

\title{
M. PAUL BERTRAND ON THE STEMS BELONGING
}

\section{TO CLEPSYDROPSIS.}

Last November M. Paul Bertrand published a short report in the "Comptes Rendus de l'Académie des Sciences" on the stems belonging to Clepsydropsis, a genus of Unger's revived for certain petioles hitherto supposed to be distinctly Botryopteridean. The best known species of Clepsydropsis is probably that described as Rachiopteris duplex by Williamson. The vascular bundle of this petiole is shaped like an hour-glass; the species is sometimes included in the genus Zygopteris, the two swollen ends of the hourglass representing thickened side-pieces of the $\mathrm{H}$-shaped trace of that genus. It is, therefore, very interesting that M. Paul Bertrand, from a careful comparison of the petiolar bundles of Clepsydropsis with the structure of the stem at the departure of the trace in Cladoxylon and in Medullosa (Steloxylon) Ludreigi, should have come to the conclusion that the first-mentioned genus represents the petioles of the two latter forms. In the case of Medullosa (Steloxylon) Ludroigi such a view is supported by the association of this type of stem with Clepsydropsis Kirgisica.

These fossils from the Lower Culm are of great antiquity, and without necessarily accepting M. Paul Bertrand's view that Clepsydropsis appears to be very primitive, and "infinitely closer than any other plant as yet described" to a form in which Lycopods, Ferns and Medullosex ultimately converge, it is obvious that the discovery that Botryopteridean petioles were associated with stems included in the Cycadofilices on account of their anatomy is very remarkable. The significance of this circumstance is enhanced by the similarity (recognized as early as 1881 by Dawson) between Cladoxylon and Asterochlaena (his Asteropteris), and by the fact that Botrychioxylon, regarded as one of the Botryopterider, possessed a considerable amount of secondary xylem. ${ }^{1}$

A certain number of Cycadofilicinean stems are now known to have belonged to seed-bearing plants and suspicion has fallen on many other's. As other Medulloseæ were certainly Pteridosperms, some doubt is naturally cast upon the cryptogamic nature of Medullosa (Steloxylon) Ludrigi, although this species is not a true or typical Medullosa. But as its petioles and those of Cladoxylon appear to belong to the same "genus" (Clepsydropsis), Cladoxylon itself may turn out to be a Pteridosperm, although further and more direct evidence would be wanted to confirm the suspicion. Further the reference of Clepsydropsis to Cycadofilicinean stems throws some doubt on the cryptogamic nature of the Botryopteridex, now frequently regarded as the most important Palæozoic group of "Ferns". ${ }^{1}$ This doubt must rest at least on the Zygoptereæ (to

'D. H. Scott. "Studies in Fossil Botany." Second Edition, Vol. I., 1908. 
which Clepsydropsis belongs), the more complex, and so for as we know, the older of the two families included in the Botryopterideæ. For these reasons M. Paul Bertrand's researches seem to be of great importance.

ISABEL BROWNE.

\section{FUNGI.}

"Synopsis of the British Basidiomycetes." A descriptive Catalogue of the drawings and specimens in the Department of Botany, British Museum ; by Worthington George Smith, F.L.S. Printed by order of the Trustees of the British Museum.

THIs book is a welcome addition to the Fungus-floras of this country. In it the author embodies the notes of many years made on the characters and distribution of the higher Basidiomycetes. The scheme of classification generally adopted is that used by Fries in his Hymenomycetes Europæi (1874), but the sub-genera of Agaricus, e.g., Amanita, Collybia, etc., used by Fries, are raised to the rank of genera, as is now indeed customary. The number of such genera is increased by the addition of Amanitopsis, Hiatula and Togaria. The genus Exobasidium, parasitic on species of Vaccinium, is still kept in the Thelephoracex, but it would seem better to assign it to a distinct group, as is done in Engler's "Pflanzenfamilien." It will be noted also that the anomalous genus Tremellodon is placed in the Hydnacex, whereas Massee assigns it to the Tremellineæ on account of its divided basidia and gelatinous consistency.

The descriptions of species in this book certainly do not err on the side of excessive length. Indeed it must be admitted that such brevity as is prevalent here will make it difficult for a beginner to be certain that his determination of species in all cases is correct. It will probably be found that he will be obliged to combine the use of this book with that of larger floras. On the other hand such long descriptions as are to be found in some other books are not desirable.

An attempt has been made to give somewhat more definite details of habitats than have been customary in former mycological floras, though it must be said that a good deal yet remains to be done in this respect. The general term "woods" is still often used as descriptive of the habitat of many of these fungi, whereas one would like to know what kind or kinds of wood are really indicated. The ecological distribution of the higher Fungi is now more widely recognised than formerly, and one looks forward to the time when a "biological" flora of the Basidiomycetes can be written.

The author of this synopsis has thoughtfully provided a glossary of special mycological terms. This will be appreciated by the 
This document is a scanned copy of a printed document. No warranty is given about the accuracy of the copy. Users should refer to the original published version of the material. 